\title{
Strategi Pemberdayaan Masyarakat dalam Pendirian Lembaga PAUD
}

\author{
Andri Hadiansyah $^{1}$, Fidesrinur $^{2}$, Masni Erika Firmiana ${ }^{3}$ \\ ${ }^{1,3}$ Program Studi Psikologi, ${ }^{2,}$ Program Studi Pendidikan Anak Usia Dini Fakultas Psikologi dan Pendidikan, \\ Universitas Al Azhar Indonesia, Kompleks Masjid Agung Al Azhar, Jl. Sisingamangaraja, Kebayoran Baru \\ Jakarta Selatan, 12110
}

Penulis untuk Korespondensi/E-mail: andri_hadiansyah@uai.ac.id

\begin{abstract}
Abstrak - Ketentuan tentang Pendidikan Anak Usia Dini (PAUD) sudah diatur dalam pasal 28 Undang-Undang Republik Indonesia Nomor 20 tahun 2003 tentang Sistem Pendidikan Nasional. Pada dasarnya banyak cara yang telah dilakukan Kementerian Pendidikan dan Kebudayaan untuk memperluas akses layanan PAUD bagi seluruh lapisan masyarakat, antara lain (1) bantuan pendirian/rintisan satuan PAUD baru, (2) bantuan pembangunan/penyediaan fasilitas PAUD, dan (3) penambahan satuan layanan PAUD yang sudah berjalan seperti TK/KB/TPA/SPS. Namun tentunya pemerintah tidak bisa bergerak sendiri, karena itu banyak lembaga atau yayasan lain yang ikut serta dalam upaya ini, salah satunya Yayasan Asih Foundation (YAF). Lembaga ini sudah berhasil memberdayakan masyarakat dalam hal pendirian dan pembinaan lembaga PAUD di seluruh Indonesia, termasuk di Jabotabek. Riset ini akan mendeskripsikan tentang strategi pemberdayaan yang diterapkan oleh Yayasan Asih Foundation. Metode penelitian yang digunakan adalah kualitatif, dengan subjek 3 sekolah di Jabotabek. Teknik pengumpulan data adalah wawancara dan observasi. Hasilnya menunjukkan bahwa pemberdayaan msyarakat yang dilakukan oleh Yayasan Asih Foundation berada di level messo. Lembaga PAUD dapat merasakan perubahan dan manfaat dari pembinaan yang diberikan oleh YAF meski pembinaan yang utama hanya berlangsung selama 2 tahun. PAUD binaan ini dapat mengembangkan diri
\end{abstract}

\section{Kata Kunci - Pendidikan Anak Usia Dini, Pembangunan Masyarakat, Pengembangan Masyarakat}

Abstract - The regulation on Early Childhood Education has been regulated in Article 28 of Law of the Republic of Indonesia Number 20 of 2003 on National Education system. Basically, many ways have been done by the Ministry of Education and Culture to expand access to early childhood education services for all levels of society, among others (1) support the establishment/ stub new Early Childhood Education unit, (2) help construction/provision of EDC facilities, (3) and the addition of early childhood services units such as TK / KB / TPA / SPS. But of course the government cannot move alone, therefore many institutions or other foundations that participate in this effort, one of the Asih Foundation. This institution has succeeded in empowering the community in terms of establishment and development of Early Childhood Education institutions across Indonesia, including in Jabotabek. This research is will described about strategy empowerment apllied by Asih Fondation. The research method used is qualitative, with the subject of 3 schools in Jabotabek.. Data collection techniques are interviews and observations. The results show that community empowerment conducted by Yayasan Asih Foundation is at the messo level. Early Childhood Education institutions can feel the changes and benefits of coaching provided by Asih Fondation even though the main coaching takes only 2 years. Early Childhood Education under supervisor of it can be developing themselves.

Keywords - Early Childhood Education, Community Development, Community Empowerment 


\section{PENDAHULUAN}

$\mathrm{P}$ embangunan pada negara-negara berkembang seperti Indonesia merupakan sesuatu unsur yang sangat penting untuk mengubah kondisi kemasyarakatan ke arah yang lebih baik. Karena pembangunan merupakan suatu rangkaian usaha mewujudkan pertumbuhan dan perubahan secara terencana dan sadar yang ditempuh oleh suatu negara bangsa menuju modernitas dalam rangka pembinaan bangsa (Siagian, 2001: 4).

Pada umumnya seluruh bidang tersebut memiliki peran yang sangat besar bagi kemajuan suatu negara. Adapun bidang yang memiliki skala prioritas utama adalah bidang ekonomi, akan tetapi dalam pembangunan ekonomi harus disertai dengan pembangunan dalam bidang-bidang yang lainnya, termasuk dalam bidang sosial budaya (Siagian, 2001: 95).

Di dalam pembangunan sosial budaya menyangkut tentang kesediaan untuk menerima perubahan dalam berbagai segi kehidupan dan penghidupan termasuk cara berfikir, gaya hidup, cara bekerja dan lain sebagainya.

Untuk itu wahana yang paling efektif dalam penyelenggaraan pembangunan sosial budaya yaitu melalui pendidikan dalam arti yang seluas luasnya. Maka menurut Siagian (2007: 109) yang dimaksud pendidikan dalam arti yang seluasluasnya adalah segala upaya yang dilakukan demi terwujudnya masyarakat modern. Artinya suatu pendidikan dapat bersifat formal yang berlangsung di lembaga-lembaga pendidikan dan dapat pula yang bersifat non formal yaitu suatu pendidikan yang terselenggara di luar "bangku sekolah" atau di luar lembaga-lembaga pendidikan.

Salah satu hal yang tidak dapat dipungkiri bahwa pendidikan adalah sebuah sarana yang efektif guna meningkatkan sumber daya manusia menjadi lebih produktif. Dengan demikian Pemerintah Pusat melalui Dinas Pendidikan Nasional mencanangkan rencana stategis menuju pembangunan jangka panjang 2025. Rencana strategis yang dijalankan oleh Dinas Pendidikan Nasional ditempuh dalam empat tahapan dengan periode lima tahunan. Periode 2005-2010 diarahkan dalam rangka peningkatan kapasitas dan modernitas sistem pendidikan, periode 2010-2015 adalah peningkatan dan penguatan pelayanan pendidikan pada tingkat nasional, priode 2015-2020 adalah penguatan daya saing pada tingkat regional, dan periode 2020-
2025 adalah penguatan daya saing pada tingkat internasional. Seluruh periode tersebut diterapkan pada pendidikan tingkat SD (Sekolah Dasar) atau MI (Madrasah Ibtidaiyah), SMP (Sekolah Menengah Pertama) atau MTs (Madrasah Tsanawiyah), SMA (Sekolah Menengah Pertama) atau SMK (Sekolah Menengah Kejuruan) atau MA (Madrasah Aliyah), TK (Taman Kanak-Kanak). Disamping itu, ditetapkan pula program PAUD (Pendidikan Anak Usia Dini). Pendidikan anak usia dini merupakan pendidikan yang sangat mendasar dan strategis dalam pembangunan sumber daya manusia. dan tidak mengherankan apabila banyak negara yang menaruh perhatian besar terhadap penyelenggaraan pendidikan anak usia dini (http://www.eldina.com).

PAUD juga telah ditetapkan dalam pasal 28 Undang-Undang Republik Indonesia Nomor 20 tahun 2003 yang menjelaskan bahwa PAUD adalah suatu upaya pembinaan yang ditujukan kepada anak sejak lahir sampai dengan usia enam tahun yang dilakukan melalui pemberian rangsangan pendidikan untuk membantu pertumbuhan dan perkembangan jasmani dan rohani agar anak memiliki kesiapan dalam memasuki pendidikan lebih lanjut. Dan Pendidikan Anak Usia Dini dapat diselenggarakan melalui jalur pendidikan formal, nonformal, dan informal. Pendidikan Anak Usia Dini dalam pendidikan formal berbentuk Taman Kanak-Kanak (TK), pendidikan anak usia dini dalam jalur nonformal berbentuk Kelompok Bermain (KB) dan Taman Penitipan anak (TPA), sedangkan pendidikan anak usia dini dalam jalur pendidikan informal berbentuk pendidikan keluarga atau pendidikan yang diselenggarakan oleh lingkungan.

Selain itu, PAUD juga telah disejajarkan dengan pendidikan lainnya. Bahkan pada puncak acara peringatan Hari Anak Nasional tanggal 23 Juli 2003, Presiden Republik Indonesia telah mencanangkan pelaksanaan pendidikan anak usia dini di seluruh Indonesia demi kepentingan terbaik anak Indonesia (Direktorat PAUD, 2004). Program PAUD tersebut bertujuan agar semua anak usia anak 0-6 tahun, baik laki-laki maupun perempuan memiliki kesempatan tumbuh dan berkembang optimal sesuai dengan potensi yang dimilikinya, sesuai tahap-tahap perkembangan atau tingkat usia mereka (http://www.junior-smart.com).

Promosi secara besar-besaran tentang PAUD baik melalui program kegiatan kemdiknas maupun sosialisasi bunda PAUD mulai menunjukkan hasil. 
Deklarasi ibu negara sebagai Bunda PAUD nasional sampai dengan bunda PAUD Propinsi, Kabupaten/Kota serta liputan media massa dan elektronik tentang perlindungan anak telah menunjukkan tumbuhnya kesadaran masyarakat akan pentingnya PAUD. Ini terbukti bahwa dari tahun ke tahun Angka Partisipasi Kasar (APK) PAUD makin meningkat dan jumlah layanan PAUD bertambah secara berarti. Namun pertumbuhan minat orang tua untuk mendidik anaknya di PAUD tidak seimbang dengan kebutuhan akan ketersediaan lembaga PAUD sehingga akses layanan PAUD masih sangat terbatas, utamanya bagi masyarakat yang kurang mampu.

Permasalahan utama dalam pendidikan di Indonesia adalah pemerataan dan akses layanan PAUD dan kualitas layanan PAUD. Permasalahan akses layanan ini antara lain disebabkan oleh pembiayaan yang terbatas, luas wilayah Indonesia ditambah lagi dengan demografi yang sangat beragam, sehingga jarak tempuh menjadi kendala utama dalam perluasan akses layanan. Sementara itu terkait dengan mutu pendidikan dipengaruhi oleh fasilitas lembaga layanan PAUD yang masih kurang dan pendidik yang masih berkualifikasi rendah.

Pada dasarnya banyak cara yang telah dilakukan Kementerian Pendidikan dan Kebudayaan untuk memperluas akses layanan PAUD diantaranya: program satu PAUD satu Desa dan di wilayah khusus, melalui: (1) bantuan pendirian/rintisan satuan PAUD baru, (2) bantuan pembangunan/penyediaan fasilitas PAUD, dan (c) penambahan satuan layanan PAUD yang sudah berjalan seperti TK/KB/TPA/SPS (Ditjen PAUDNI, 2013: 45). Semua program yang dikembangkan oleh pemerintah ini belum mampu menjangkau jumlah anak usia dini yang perlu pelayanan. Terkait dengan jumlah yang perlu diperjuangkan untuk layanan PAUD diproyeksikan penambahan satuan PAUD dengan data dasar 237.176 lembaga (2009), maka pada periode percepatan perluasan layanan PAUD (2011-2015) setiap tahun dibutuhkan tambahan sekitar 32.000 sampai dengan 42.000 satuan layanan PAUD baru (Ditjen PAUDNI, 2013:45).

Selain permasalahan masih terbatasnya layanan atau kekurangan jumlah lembaga untuk pelayanan PAUD, masalah keberlanjutan lembaga pendidikan yang telah berdiri juga merupakan masalah yang tidak kalah pentingnya. Tidak sedikit lembaga PAUD yang menghadapi permasalahan dalam pengembangan PAUD baik karena terbatasnya tenaga pendidik yang kompeten maupun karena terbatasnya kemampuan keuangan sehingga tidak mampu menutupi biaya operasional. Akhirnya lembaga PAUD tersebut ditutup.

Yayasan Asih Foundation merupakan salah satu yayasan yang telah sukses mendirikan puluhan lembaga PAUD di seluruh Indonesia, termasuk di daerah Jabodetabek. Yayasan Asih Foundation dengan visi berkomitmen menumbuhkan kembangkan potensi kemandirian masyarakat yang bertumpu pada sumber daya lokal berbasis pada program pendidikan anak usia dini. Melalui misi Yayasan Asih Foundation untuk: (1) membangun diri menjadi lembaga yang berfungsi sebagai motor pertumbuhan program pendidikan anak usia dini, (2) menumbuhkan jejaring sosial elemen pembangunan (pemerintah, perusahaan, lembaga swasemabada masyarakat dan warga masyarakat), (3) mendorong lahirnya sarana pendidikan anak usia dini yang merakyat, dan (4) mengadvokasi paradigma pendidikan bagi anak usia dini dan hak belajar anak-anak jalanan.

Keikutsertaan Yayasan Asih Foundation dalam mendirikan dan mengembangkan PAUD sampai mandiri ini di kalangan masyarakat kurang mampu patut menjadi model pengembangan PAUD. Yayasan seperti ini diperlukan untuk mendukung program pemerintah yang belum mampu menjangkau masyarakat terbawah. Disamping itu Yayasan Asih Foundation juga memperhatikan keberlanjutan lembaga PAUD yang didirikan sehingga terus dapat melayani masyarakat kurang mampu di lembaga PAUD yang didirikan.

Permasalahan utama pendidikan di Indonesia termasuk masalah PAUD adalah masalah akses layanan dan kualitas layanan PAUD. Pemerintah dihadapkan pada permasalahan yang pelik antara kualitas layanan PAUD di satu sisi dan kuantitas layanan PAUD di sisi lainnya. Kuantitas terkait dengan akses pendidikan bagi seluruh anak Indonesia yang diyakini berdampak pada pendidikan lanjut dan masa depan anak kelak di masa dewasanya. Keterbatasan pendanaan pemerintah untuk menjangkau semua anak mengharuskan lembaga PAUD mencari sumbersumber pembiayaan lain selain dari pemerintah baik untuk mendirikan lembaga PAUD yang baru maupun untuk keberlanjutan lembaga PAUD yang telah berdiri. Untuk itu setiap lembaga harus 
mengembangkan sumber-sumber pembiayaan sendiri untuk memperkuat lembaganya masingmasing sehingga eksistensi lembaga dapat berkelanjutan sekaligus dapat meningkatkan kualitas layanannya. Untuk itu perlu belajar dari Yayasan yang telah mendirikan lembaga PAUD bersama masyarakat yang kemudian dilepas secara mandiri dan dikelola oleh masyarakat setempat.

Pemberdayaan masyarakat, utamanya orang tua peserta didik merupakan faktor penting dalam mendorong kemandirian dalam pengembangan serta keberlanjutan lembaga PAUD. Kemandirian yang didorong oleh program Yayasan Asih Foundation dapat dijadikan pembelajaran bagi lembaga PAUD yang umumnya mengalami permasalahan yang sama dalam pemberdayaan masyarakat. Disamping itu sumber-sumber pembiayaan dan pendanaan yang biasanya penyebab utama ketidakberlanjutan lembaga PAUD dapat diketahui melalui pengalaman Yayasan Asih Foundation dalam mendorong lembaga PAUD yang mandiri. Kemandirian lembaga PAUD penting artinya dalam upaya peransertanya dalam mencerdaskan kehidupan bangsa, melalui akses dan peningkatan mutu secara berkelanjutan pada anak usia dini. Dengan akses dan kualitas yang selalu meningkat diharapkan akan berkontribusi pada pendidikan anak selanjutnya dan diharapkan dapat meningkatkan kualitas hidup kelak di masa dewasanya.

\section{KERANGKA TEORI}

\section{Pemberdayaan Masyarakat}

Secara konseptual, pemberdayaan atau pemberkuasaan (empowerment), berasal dari kata 'power' (kekuasaan atau keberdayaan). Karenanya, ide utama pemberdayaan bersentuhan dengan konsep mengenai kekuasaan. Kekuasaan seringkali dikaitkan dengan kemampuan kita untuk membuat orang lain melakukan apa yang kita inginkan, terlepas dari keinginan dan minat mereka. Ilmu sosial tradisional menekankan bahwa kekuasaan berkaitan dengan pengaruh dan kontrol. Pengertian ini mengasumsikan bahwa kekuasaan sebagai sesuatu yang tidak berubah atau tidak dapat dirubah.

Keberdayaan masyarakat merupakan unsur dasar yang memungkinkan suatu masyarakat bertahan, dan dalam pengertian yang dinamis mengembangkan diri dan mencapai kemajuan.
Keberdayaan masyarakat itu sendiri menjadi sumber dari apa yang di dalam wawasan politik disebut sebagai ketahanan nasional. Artinya bahwa apabila masyarakat memiliki kemampuan ekonomi yang tinggi, maka hal tersebut merupakan bagian dari ketahanan ekonomi nasional.

Sedangkan pendapat lain dikemukakan oleh Parsons bahwa :

"Pemberdayaan adalah sebuah proses dengan mana orang menjadi cukup kuat untuk berpartisipasi dalam, berbagi pengontrolan atas, dan mempengaruhi terhadap, kejadian-kejadian serta lembaga-lembaga yang mempengaruhi kehidupannya. Pemberdayaan menekankan bahwa orang memperoleh keterampilan, pengetahuan, dan kekuasaan yang cukup untuk mempengaruhi kehidupannya dan kehidupan orang lain yang menjadi perhatiannya" (Parsons, 1994: 106). Pemberdayaaan dalam konsep Parsons menekankan agar memperoleh keterampilan, pengetahuan dan kekuasaan bagi yang memberdayakan maupun yang diberdayakan agar mereka memiliki kekuatan untuk berpartisipasi dalam kehidupan sosial dan dapat mengendalikan pengaruh-pengaruh dari kejadian-kejadian disekitarnya.

Edi Suharto mengungkapkan definisi pemberdayaan lebih luas lagi sebagai berikut:

"Pemberdayaan dapat dinyatakan bahwa pemberdayaan adalah sebuah proses dan tujuan. Sebagai proses, pemberdayaan adalah serangkaian kegiatan untuk memperkuat kekuasaan atau keberdayaan kelompok lemah dalam masyarakat, termasuk individu-individu yang mengalami masalah kemiskinan. Sebagi tujuan, maka pemberdayaan menunjuk pada keadaan atau hasil yang ingin dicapai oleh sebuah perubahan sosial; yaitu masyarakat miskin yang berdaya, memiliki kekuasaan atau mempunyai pengetahuan dan kemampuan dalam memenuhi kebutuhan hidupnya baik yang bersifat fisik, ekonomi, maupun sosial seperti memiliki kepercayaan diri, mampu menyampaikan aspirasi, mempunyai mata pencaharian, berpartisipasi dalam kegiatan sosial, dan mandiri dalam melaksanakan tugas-tugas kehidupannya. Pengertian pemberdayaan sebagai tujuan seringkali digunakan sebagai indikator keberhasilan pemberdayaan sebagai sebuah proses" (Suharto, 2002: 6).

Upaya memberdayakan masyarakat menurut Kartasasmita (1996: 159) harus dilakukan melalui tiga langkah yaitu: 
1. Menciptakan suasana yang memungkinkan masyarakat berkembang (enabling);

2. Memperkuat potensi atau daya yang dimiliki oleh masyarakat (empowering);

3. Memberdayakan juga dapat diartikan sebagai melindungi.

Prijono (1996: 97) berpendapat bahwa memberdayakan rakyat mengandung makna mengembangkan, memandirikan, mensadarkan dan memperkuat potensi tawar-menawar masyarakat lapisan bawah terhadap kekuatankekuatan penekan disegala bidang dan sektor kehidupan, disamping itu juga mengandung arti melindungi dan membela denggan berpihak kepada yang lemah, untuk mencegah terjadinya persaingan yang tidak seimbang dan eksploitasi yang lemah.

Pandangan lain dikemukakan juga oleh Kiefer dalam Prijono dan Pranarka (1996: 72) bahwa:

"Empowering is an interactive and higly subjective relationship of individuals and their environment, it demand innovation in qualitativel ethnographic methodology and special strategy to capture the intens experience ofhuman struggle and tranformation. Pemberdayaan adalah saling terkait dan mempunyai hubungan yang sangat subjektif pada individu dengan pemberdayaan itu sendiri, yang membutuhkan inovasi yang berkualitas dengan metodologi dan strategi tertentu untuk menangkap pengalaman yang berkesinambungan dalam perjuangan manusia dan perubahannya".

Pemberdayaan masyarakat adalah sebuah konsep pembangunan ekonomi yang merangkum nilainilai sosial. Konsep ini mencerminkan paradigma baru pembangunan, yakni yang bersifat "people centred, participatory, empowering, and sustainable" (Chambers, 1995). Konsep ini lebih luas dari hanya semata-mata memenuhi kebutuhan dasar (basic needs) atau menyediakan mekanisme untuk mencegah proses kemiskinan lebih lanjut (safety net), yang pemikirannya belakangan ini banyak dikembangkan sebagai upaya mencari alternatif terhadap konsep-konsep pertumbuhan di masa yang lalu. Konsep ini berkembang dari upaya banyak ahli dan praktisi untuk mencari apa yang antara lain oleh Friedman (1992) disebut sebagai alternative development, yang menghendaki "inclusive democracy, appropriate economic growth, gender equality and intergenerational equaty". (Kartasasmita, Ginanjar 1997)
Menurut Bryant dan White (1989: 25), Pemberdayaan hendaknya dipahami sebagai suatu proses meningkatkan kemampuan masyarakat sehingga mereka dapat memecahkan masalahnya sendiri dengan cara memberikan kepada mereka kepercayaan untuk mengelola program-program tertentu atas keputusannya sendiri. Sementara itu Soetrisno (1995), mendefinisikan partisipasi merupakan kerjasama antara rakyat dan pemerintah dalam merencanakan, melaksanakan, melestarikan dan mengembangkan hasil pembangunan. Dalam pengertian ini rakyat diasumsikan mempunyai aspirasi, nilai budaya yang perlu diakomodasikan dalam proses perencanaan dan pelaksanaan suatu program pembangunan. Sedangkan menurut Bryant dan White (1989), mendefinisikan peran serta sebagai keterlibatan diri masyarakat dalam penyusunan rencana dan pelaksanaan proyek. Jadi partisipasi dalam hal ini dapat diartikan sebagai keterlibatab masyarakat setempat secara aktif dalam pengambilan keputusan, baik dalam perencanaan maupun pelaksanaan terhadap proyek-proyek pembangunan untuk masyarakat.

Weissglass (1990: 351-370), memberikan suatu pengertian tetntang pemberdayaan bahwa pemberdayaan menurutnya sebagai "A process of supporting people to contruct new meaning and exercise their freedom to choose", artinya suatu proses yang membangkitkan masyarakat untuk membangun makna dan menggunakan hak kebebasan untuk menentukan pilhan yang baru. Sementara itu menurut Irwin (1995: 82):

"Empowering other people means giving them a cance to make their special contribution ... your contribution may be a particular talednt, a particular energy, a particular loving way be with people" upaya memberdayakan masyarakat itu berarti memberikan kepada masyarakat peluang untuk melibatkan diri dengan hal-hal yang menyangkut paham, bakat, kekuatan dan kesenangan masyarakat" (Irwin 1995: 82). Menurut Sumodiningrat (1999), bahwa pemberdayaan masyarakat merupakan upaya untuk memandirikan masyarakat lewat perwujudan potensi kemampuan yang mereka miliki. Adapun pemberdayaan masyarakat senantiasa menyangkut dua kelompok yang saling terkait, yaitu masyarakat sebagai pihak yang diberdayakan dan pihak yang menaruh kepedulian sebagai pihak yang memberdayakan. 
Secara konseptual, pemberdayaan masyarakat adalah upaya untuk meningkatkan harkat dan martabat lapisan masyarakat yang dalam kondisi sekarang tidak mampu untuk melepaskan diri dari perangkap kemiskinan dan keterbelakangan. Dengan kata lain memberdayakan adalah memampukan dan memandirikan masyarakat. Pemberdayaan masyarakat adalah upaya untuk menciptakan/meningkatkan kapasitas masyarakat, baik secara individu maupun berkelompok, dalam memecahkan berbagai persoalan terkait upaya peningkatan kualitas hidup, kemandirian, dan kesejahteraannya. pemberdayaan masyarakat memerlukan keterlibatan yang lebih besar dari perangkat peerintah daerah serta berbagai pihak untuk memberikan kesempatan dan menjamin keberlanjutan berbagai hasil yang dicapai.

Dengan demikian disimpulkan bahwa pemberdayaan masyarakat adalah sebuah proses dengan mana orang menjadi kuat untuk berpartisipasi dalam berbagai pengontrolan atas, dan mempengaruhi terhadap, kejadian-kejadian serta lembaga-lembaga yang mempengaruhi kehidupanya. Pemberdayaan menekankan bahwa orang memperoleh keterampilan, pengetahuan, dan kekuasaan yang cukup untuk mempengaruhi kehidupannya dan kehidupan orang lain yang menjadi perhatiannya

\section{Intervensi Sosial}

Intervensi sosial didefinisikan sebagai tindakan yang bertujuan untuk membantu orang perorangan atau kelompok, atau keluarga, atau komunitas dalam konteks kehidupan sosial mereka (Hardjomarsono ,2007: 1.4). Johnson (dalam Hardjomarsono, (2007: 1.4) menyatakan bahwa intervensi sosial adalah :

1. Tindakan spesifik yang dikerjakan oleh pelaku intervensi yang terkait dengan upaya untuk menimbulkan perubahan

2. Sebuah alat yang digunakan oleh pelaku intervensi sosial untuk memecahkan masalahmasalah dengan cara yang rasional.

Berdasarkan definisi tersebut, terlihat bahwa Intervensi sosial bertujuan untuk membantu target mengalami perubahan yang diinginkan. Selain itu, dapat terlihat juga bahwa ada beberapa komponen dalam intervensi sosial: pelaku intervensi, target intervensi, pemecahan masalah, dan perubahan. Dalam riset ini, pelaku intervensi sosial adalah Yayasan Asih Foundation, targetnya adalah kelompok masyarakat yang membutuhkan lembaga PAUD, yang membutuhkan perubahan dengan pemecahan masalah pendidikan untuk

\section{PAUD-nya.}

Manfaat Intervensi sosial setelah beroleh intervensi, diharapkan target mengalami perubahan:

1. Target dapat beroleh kembali keberfungsian sosial selaku anggota masyarakat yang baik.

2. Memperoleh kemampuan untuk mengatasi gangguan yang dihadapi target.

3. Meningkatkan kemampuan mengatasi masalah dalam kehidupannya dengan teknik penyelesaian yang baik.

4. Lebih mampu menjalankan peranan-peranan yang baru sesuai dengan perkembangan dirinya sehingga gangguan serupa dapat dicegah supaya tidak berulang lagi.

Upaya intervensi dalam konteks sosial dapat dipilih sebagai berikut :

1. Memberikan bantuan untuk memulihkan keberfungsian sosial seseorang, orang-orang, keluarga, kelompok atau komunitas sebagai warga keluarga, warga kelompok atau komunitas yang layak.

2. Mencakup kegiatan-kegiatan lain untuk mengatasi atau mencegah timbulnya masalah-masalah.

3. Mencapai tujuan perbaikan sosial.

4. Membantu atau mendorong target untuk mengalami perubahan atau perkembangan yang diinginkan.

Berdasar 4 (empat) hal tersebut di atas, tujuan intervensi sosial dapat dipilah lagi menjadi :

1. Bersifat kuratif dan korektif (butir 1),

2. Preventif (butir 2)

3. Promotif (butir 3)

4. Pengembangan atau developmental (butir 4), jika intervensi dilakukan dengan kemungkinan untuk mengembangkan diri target.

Dalam riset ini berdasar observasi awal, tujuan intervensi butir 1, 2, dan 3 telah dilakukan oleh Yayasan Asih. Jika dilakukan pengumpulan data yang lebih mendalam, mungkin tim peneliti akan menemukan bahwa yayasan Asih Foundation sudah mencapai 4 (empat) tujuan tersebut. Tidak dapat dipungkiri bahwa dalam pelaksanaan intervensi sosial, perlu melewati proses perencanaan, penerapan, juga evaluasi program, dimana di dalamnya merancang kegiatan yang bersifat korektif, preventif, promotif, bahkan developmental untuk lebih mempercepat pencapaian program yang dirancang. 


\section{Metode Intervensi Sosial}

Metode intervensi sosial yang sering digunakan adalah sebagai berikut (Hardjomarsono, 2007: 1.10):

1. Praktik mikro, yang terutama memusatkan perhatian pada pelayanan langsung pada orang per orang berdasarkan layanan kasus demi kasus. Praktik mikro umumnya dilakukan di badan-badan intervensi klinis

2. Praktik mezzo, ditujukan untuk pemberian bantuan bagi keluarga dan kelompok kecil. Kegiatan pada jenjang ini mencakup memberikan layanan komunikasi, mediasi, bernegosiasi, mendidik dan mengajak orangorang bertemu untuk bersama-sama memecahkan masalah yang dihadapi

3. Praktik makro, yang diarahkan untuk mendatangkan perbaikan dan perubahanperubahan dalam komunitas (masyarakat). kegiatan semacam ini meliputi beberapa tipe intervensi seperti aksi politik (misalnya penyusunan undang-undang baru), pembangunan masyarakat, gerakan pendidikan masyarakat, administrasi badan sosial yang mempunyai layanan yang luas dan badan-badan kesejahteraan publik lainnya

Berdasarkan observasi awal, dalam hal pembinaan PAUD, Yayasan Asih Foundation menerapkan metode praktik makro, dimana kegiatan yang dilaksanakan adalah menggerakkan masyarakat untuk membangun lembaga PAUD di lingkungannya. Mengingat lembaga ini sudah menerapkan hal tersebut selama bertahun-tahun, jika dilakukan penelitian dan pengumpulan data yang lebih mendalam maka bisa saja akan ditemukan bahwa mereka sudah menerapkan ketiganya sekaligus.

Pelaksanaan Intervensi sosial, diawali dengan adanya masalah sosial yang harus dipecahkan atau diselesaikan. Setelah pelaku intervensi mengidentifikasi permasalahan, akan dirancang suatu kegiatan perubahan yang terencana. Kegiatan perubahan terencana ada yang dibuat sendiri oleh pelaku intervensi, ada yang kolaborasi antara pelaku intervensi dengan target intervensi. Selanjutnya, kegiatan intervensi dapat dimulai setelah adanya assessmen terkait target intervensi. Selanjutnya pelaku intervensi akan melaksanakan kegiatan yang sudah dirancang dengan menerapkan sejumlah teknik-teknik intervensi. Bagian ini disebut dengan proses pemberian pengaruh. Untuk dapat melakukan pemberian pengaruh secara terampil, seorang pelaku intervensi perlu memiliki keterampilan dalam hal (Hardjomarsono, 2007: 6.3) :

1. Pengetahuan dan keahlian/kepakaran

2. Sumber-sumber pelayanan material

3. Kewenangan

4. Status dan reputasi

5. Kharisma dan daya tarik pribadi

6. Kontrol terhadap arus informasi

7. Relasi-relasi yang telah mapan

Untuk melaksanakan tujuh hal ini dengan baik, dilakukan dengan empat cara utama (Hardjomarsono, 2007: 6.3):

1. Pemaksaan (inducement)

2. Persuasi

3. Penggunaan relasi

4. Penggunaan lingkungan.

\section{Pembiayaan dan Pendanaan PAUD}

Pertanyaan yang mendasar yang sering dipertanyakan dalam pendirian lembaga PAUD adalah berapa besar biaya yang diperlukan dalam pengembangan PAUD? Pertanyaan ini tidak mudah untuk dijawab karena masing-masing jenis layanan PAUD berbeda satu sama lainnya. Menurut Barnett (2000: 590) berbagai jenis layanan dan keluarga yang dilayani dengan berbagai program layanan yang diperlukan keluarga tersebut. Variasi gaji, sewa dan hargaharga barang lainnya di daerah setempat juga dapat membedakan biaya layanan PAUD.

Berkaitan dengan biaya layanan program sebagaimana dikemukakan sebelumnya maka pendanaan dalam penyelenggaraan PAUD menurut Decker dan Decker (1992: 252) sangat penting karena betapapun bagusnya program PAUD yang akan dikembangkan tidak akan terlaksana apabila dana sangat terbatas. Keterbatasan dana akan berdampak pada prioritas program yang mungkin dilakukan karena masingmasing bentuk dan kualitas program layanan PAUD berbeda-beda disamping juga dipengaruhi keadaan wilayah geografis.

Selanjutnya hal penting yang perlu diperkirakan dalam pendanaan menurut Decker dan Decker (1992: 255) adalah pemasukan atau penerimaan. Terkait dengan penerimaan ini harus dipastikan sumber uang masuk dengan pasti misalnya; SPP, sumbangan, dan penyandang dana. Sumber masuk dari orang tua seperti SPP dan sumbangan orang tua juga berbeda dari suatu wilayah dengan wilayah lainnya. Berkaitan dengan partisipasi orang tua tersebut Barnett (2000: 595) di negara- 
negara maju seperti Amerika Serikat pemungutan SPP biasanya jarang terjadi, kalau dipungut biaya SPP jumlahnya sangat kecil. Dua hal yang berkaitan dengan SPP adalah apabila biaya administratif dan biaya pengumpulan lebih besar dari SPP yang akan dikumpulkan maka partisipasi dalam pengumpulan SPP menjadi lebih rendah. Namun demikian walaupun SPP rendah dan pembayaran disesuaikan dengan kemampuan, keluarga yang kurang kemampuan untuk membayar menunjukkan penghargaan terhadap nilai pelayanan program. Pembiayaan seringkali tidak disadari apabila orang tua dijadikan sumber belajar mengantar jemput anak dan hal-hal seperti seringkali tidak diperhitungkan sehingga orang tua menganggap biaya pendidikan ekonomis. Dalam kaitan itu Farran (2000: 525) mengemukakan bahwa tidak satupun penilaian terhadap program akan berbeda-beda apabila dikaitkan dengan penghasilan orang tua, kondisi perumahan, kecuali fakta menunjukkan bahwa keluarga yang dipilih untuk suatu program karena benar-benar berasal dari keluarga yang memiliki penghasilan yang sangat rendah.

Program Yayasan Asih Foundation yang dikembangkan dari visi dan misi yang dikemukakan sebelumnya dalam latar belakang maka tujuan Yayasan Asih Foundation adalah untuk: (1) meningkatkan profesionalitas lembaga, (2) meningkatkan otonomi jaringan lembaga pendidikan anak usia dini melalui devolusi (desentralisasi dan pelimpahan wewenang), (3) meluasnya pemahaman, penerimaan dan pelaksanaan pendidikan bagi anak usia dini, (4) meningkatkan pendayagunaan aset masyarakat melalui pengelolaan Corporate Social Responsibility (CSR) dan derma sehingga tercapainya kemandirian komunitas sasaran. Program ini sangat dekat dengan masyarakat dengan dukungan Yayasan Asih Foundation. Yayasan disamping menyediakan dana awal dan mendukung manajemen sampai mandiri dapat memberikan motivasi dan keyakinan dalam pemberdayaan masyarakat. Dukungan terhadap masyarakat sangat dibutuhkan sekali pada saat kemampuan pemerintah secara finasial sangat terbatas.

Berbeda halnya dengan negara maju seperti di Amerika Serikat, pada tahun 1987 NAEYC dalam Decker dan Decker (1992: 239) telah mendeklarasikan bahwa: pertama, setiap anak harus memperoleh layanan PAUD yang berkualitas dan untuk itu; (1) guru terlatih diperlukan untuk mengimplementasikan kurikulum yang sesuai dengan perkembangan anak dan (2) rasio anak dan guru berdasarkan kebutuhan sesuai usia harus dapat melayani anak sesuai kebutuhan dan dipastikan bahwa anak pengalaman belajar yang diperlukan; kedua, program PAUD harus dapat menggaji guru PAUD sesuai dengan keterampilan dan kualifikasinya sehingga dapat menjalankan tugasnya secara berkualitas; dan ketiga, kualitas PAUD yang tinggi harus tersedia bagi setiap keluarga yang membutuhkan, dengan biaya yang terjangkau. Deklarasi ini memungkinkan karena perekonomian masyarakat dan kesadaran pentingnya PAUD sangat tinggi. Sehingga akses layanan dan kualitas layanan dapat dilakukan dengan baik.

Berkaitan dengan keterbatasan pembiaayan pada program PAUD untuk masyarakat kurang mampu maka penjelasan Decker dan Decker dapat dijadikan panduan penerimaan bagi lembaga PAUD. Menurut Decker dan Decker (1992: 246252) pembiayaan bagi PAUD negeri biasanya berasal dari Kabupaten/Kota, propinsi dan negara. Sementara itu sumber pembiayaan lainnya dapat diperoleh dari Yayasan baik Yayasan masyarakat, organisasi nirlaba yang memberikan bantuan sesuai dengan proposal yang diajukan lembaga PAUD. Sementara itu bagi program PAUD lainnya juga dapat menarik SPP secara penuh atau mendapat keringanan dari penyandang dana lainnya.

Berdasarkan uraian di atas diketahui bahwa pembiayaan dan pendanaan yang diperlukan ditentukan oleh jenis layanan yang dikembangkan serta partisipasi peserta didik dalam pembiayaan pendidikan. Dari penjelasan tentang pendanaan dan pembiayaan PAUD dapat disimpulkan bahwa sumber-sumber pembiayaan baik dari pemerintah pusat, propinsi, serta Kabupaten/Kota dan sumber lainnya yang tidak mengikat dan sumbangan orang tua murid perlu digali dan didayagunakan untuk keberlanjutan lembaga PAUD.

\section{METODE PENELITIAN}

\section{Metode Penelitian}

Penelitian ini bersifat kualitatif, dan dimaknai secara mendalam berdasarkan perspektif emik yaitu penyajian data secara alamiah tanpa melakukan suatu manipulasi atau perlakuan terhadap subjek yang diteliti (Bogdan dan Taylor, 1975: 31). Disamping itu data deskriptif yang diisi 
oleh pengurus dan pendidik PAUD diperkuat melalui triangulasi data melalui observasi dan wawancara pada pengurus dan pendidik PAUD, orang tua, dan masyarakat sekitar sekolah.

\section{Tempat dan Waktu Penelitian}

Penelitian dilaksanakan di 3 (tiga) lembaga PAUD di bawah binaan Yayasan Asih Foundation yang berada di Wilayah Jabodetabek. Sedangkan waktu penelitian berlangsung selama 5 (lima) bulan.

\section{Ruang Lingkup dan Objek Penelitian}

Ruang lingkup dan objek penelitian meliputi halhal sebagai berikut :

a. Wilayah penelitian dibatasi pada lembaga PAUD di Jabodetabek di bawah binaan Yayasan Asih Foundation.

b. Sasaran Penelitian adalah pengurus yayasan, kepala sekolah dan guru PAUD di lembaga binaan Yayasan Asih Foundation.

c. Penelitian hanya mengkaji kebijakan yayasan dalam pendirian dan pengembangan PAUD.

\section{Alat Pengumpul Data}

Alat pengumpulan data yang digunakan dalam penelitian ini adalah pedoman wawancara. Selain itu, pengumpulan data juga dilakukan dengan observasi. Wawancara dan observasi digunakan untuk triangulasi data terhadap subjek dan informan kunci.

\section{Pengolahan dan Analisis Data}

Berdasarkan data primer dan data sekunder yang diperoleh, maka data selanjutnya diolah dan dianalisis dengan menggunakan analisis Kualitatif melalui hasil deskripsi observasi dan wawancara dengan responden.

\section{HASIL DAN PEMBAHASAN}

\section{Profil Yayasan ASIH Foundation}

Yayasan Asih Foundation (selanjutnya diistilahkan YAF) adalah sebuah yayasan yang berdiri pada 10 Desember 2007. Yayasan ini didirikan oleh Miranty Abidin, Didik J Rachbini, dan Hendro Martowardojo. Berawal dari adanya pemikiran bahwa perhatian yang diberikan pemerintah terhadap pendidikan anak usia dini masih relatif rendah, YAF mewujudkan sebuah wadah yang memfokuskan kegiatan di bidang pendidikan bagi anak-anak berusia 2-4 tahun atau Lembaga Pendidikan Anak Usia Dini (Lembaga PAUD).

Perhatian YAF terutama untuk anak-anak dari keluarga tidak mampu dan yatim piatu. YAF juga berkomitmen untuk selalu menumbuhkembangkan sebanyak mungkin anak kurang mampu dengan sarana pendidikan anak usia dini yang memadai. Dengan segala daya, YAF terus berupaya mewujudkan tempat-tempat belajar bagi anak usia dini. YAF berkomitmen menumbuhkembangkan potensi AUD dengan kemandirian masyarakat yang bertumpu pada sumber daya lokal berbasis pada program pendidikan anak usia dini (PAUD).

Misi YAF adalah menjadi wadah yang berfungsi sebagai motor pertumbuhan program PAUD, menumbuhkembangkan jejaring sosial elemen pembangunan, seperti pemerintah, perusahaan, lembaga swadaya masyarakat, dan warga masyarakat yang peduli. Saat ini, setidaknya YAF telah membangun tak kurang dari 37 PAUD yang tersebar di wilayah kantong kemiskinan di Jabodetabek dan di berbagai wilayah di Indonesia termasuk di Kabupaten Solok Selatan Provinsi Sumatera Barat, serta Kalimantan Timur. Untuk wilayah Jabodetabek saja setidaknya telah terwujud 25 PAUD, antara lain pada 6 Desember 2011 didirikan di daerah Parung, Bogor. Saat ini PAUD binaan YAF setidaknya telah menampung seribuan lebih anak usia dini, dan memberdayakan ratusan guru PAUD.

Sebagai suatu lembaga, Asih Foundation tidak bekerja sendiri, namun juga membuka peluang bekerja sama dengan banyak pihak. YAF membuka peluang bagi tokoh masyarakat dan pengusaha untuk bekerjasama membuka beberapa tempat PAUD di wilayah yang warganya masih di bawah garis kemiskinan dan tidak mampu.

YAF juga membangun sistem untuk saling berbagi antar PAUD binaan. Tujuannya adalah untuk menjalin komunikasi antar PAUD dengan YAF. Selian itu, YAF menggelar pertemuan dengan seluruh pengurus dan guru-guru, setahun dua kali. Tujuan berkumpul ini adalah untuk saling sharing sekaligus silaturahmi. Berdasarkan kegiatan tersebut, YAF menemukan masalah yang muncul kemudian adalah bahwa ternyata bukan hanya fasilitas fisik yang dibutuhkan oleh masyarakat tersebut, tapi juga diperlukan upaya-upaya pemberdayaan masyarakat yang nantinya akan menjadi tenaga-tenaga pengelola sarana pendidikan tersebut. Salah satu bentuknya adalah dengan memberdayakan masyarakat (khususnya Ibu dan anggota posyandu) sekitar sebagai tenaga pengajar di sekolah-sekolah alternatif di beberapa wilayah tersebut 


\section{Profil Lembaga PAUD Binaan YAF PAUD Yasmin}

Lembaga PAUD ini berlokasi di MAUK, Tangerang, sekitar 2 jam perjalanan dari Jakarta. Lembaga PAUD ini berdiri pada tahun 2008. Berawal dari satu ruangan kecil, milik $\mathrm{Bu}$ Tohariyah (Itoh), yang sekarang menjadi kepala sekolah. Dalam rentang beberapa waktu, akhirnya Lembaga PAUD sudah memiliki 5 (lima) ruangan, dan 1 kamar mandi/toilet yang relatif cukup memadai.

Keorganisasian di sekolah ini adalah : 1 kepala sekolah (merangkap pendidik PAUD), dan 6 (enam) orang pendidik PAUD. Kualifikasi pendidikan pendidik di sini adalah : kepala sekolah lulus S2, 2 (dua) orang pendidik PAUD sudah S1, sisanya sedang dalam proses menyelesaikan S1. Pembiayaan perkuliahan mereka saat ini ditanggung sendiri.

Kendala pelaksanaan pendidikan di Lembaga PAUD selama ini adalah sarana prasarana bangunan. Jika di lokasi hujan deras, wilayah tersebut seringkali banjir, karena lokasi bangunan yang lebih rendah daripada jalan raya. Pendiri dan pendidik merasa perlu mencari lokasi yang lebih baik, tetapi belum ada dana. Selama ini pendanaan mengandalkan dana pribadi pendiri lembaga PAUD.

\section{PAUD Islam Nurunnajah}

Lembaga PAUD ini berlokasi tidak jauh dari PAUD Yasmin, masih berada dalam lingkup HIMPAUDI Kecamatan yang sama. Lembaga PAUD ini berdiri sejak 2008, dengan "modal" 1 ruangan dari rumah pribadi milik kepala sekolah. Saat ini ruang kelas sudah menjadi 3 ruangan. Kegiatan PAUD dibagi menjadi 2 shift, pagi dan sore. Kondisi kelas, juga sarana lainnya cenderung lebih minim daripada Lembaga PAUD Yasmin. Ruangan kelas lebih sempit, kecil, dan minim cahaya. Selain itu sarana permainan untuk anak juga cenderung sangat terbatas. Dengan keterbatasan dana, saat ini, lembaga PAUD Islam Nurunnajah sedang melakukan pembangunan tambahan ruangan kelas, dengan dana pribadi. Jumlah guru hanya 5 (lima) orang, 3 (tiga) di antaranya sedang menyelesaikan pendidikan S1. Kepala sekolah mengeluhkan tentang pandangan orang tua yang menuntut supaya anak sudah harus dapat membaca, menulis dan berhitung (ini tidak sesuai dengan tuntunan kurikulum untuk PAUD, karena masa kanak-kanak adalah masa bermain).

\section{PAUD Baitul Uyun, Cengkareng}

PAUD Baitul Uyun berdiri pada tahun 2004, di bawah Yayasan Baitul Uyun dengan ketua yayasan Drs. Rusdi. Kepala Sekolahnya bernama Ibu Haulah, dan saat ini guru / pendidik PAUD berjumlah 7 (tujuh) orang. Sarana /prasarana sekolah dapat dikatakan jauh dari standar minimal untuk lembaga PAUD. Bangunan fisik sekolah terpisah menjadi dua bangunan. Bangunan pertama saat ini sudah menjadi milik yayasan, berukuran $60 \mathrm{~m} 2$; sedangkan bangunan ke dua masih menyewa kepada warga, berukuran 50m2. Posisi kedua bangunan berseberangan, dengan jarak hanya sekitar $1,5 \mathrm{~m}$ yang juga sebagai jalan umum bagi warga, dan kendaraan bermotor sering berlalu lalang. Dengan demikian, keamanan pendidik serta peserta didik di lembaga terkait juga menjadi kurang terjamin. Selain itu, sarana bermain di luar kelas dan di dalam bangunan sangat minim, dapat dikatakan tidak ada.

\section{Bentuk Peran Yayasan Asih Foundation}

Berdasarkan temuan data di lapangan, peneliti menemukan bentuk peran yayasan Asih Foundation, yaitu :

a. Bagi Masyarakat di sekitar Lembaga PAUD yang diasuh oleh Yayasan Asih Foundation.

Sebagai mitra kerja, masyarakat ikut andil dalam menentukan dan menetapkan model pembelajaran sesuai dengan kondisi yang terjadi di lingkungan mereka. Wujud dari hal itu adalah saat pembentukan pendidikan PAUD, Yayasan Asih Foundation bersama masyarakat mengadakan pertemuan - pertemuan untuk merumuskan Visi dan Misi, guna menyatukan langkah dalam pelaksanaannya nanti.

Hal ini seperti yang disampaikan oleh Kepala Sekolah PAUD Yasmin :

"Untuk pendirian lembaga kami dulu, para tokoh masyarakat diajak berkumpul dulu, 'Bun. Awalnya dulu saya ajak semua untuk berkumpul, dan membahas masalah ini bersama-sama. Tetapi sepertinya sharing saya dulu itu belum terlalu membuka pemikiran para tokoh sini [...] Akhirnya setelah ketemu dengan $\mathrm{Bu}$ Yati dari Asih, saya minta beliau untuk lebih meyakinkan para tokoh sini, Alhamdulillaah berhasil Bun. Masyarakat terbuka pemikirannya".

Hal senada juga disampaikan oleh Kepala Sekolah PAUD Islam Nurunnajah,

"Awalnya saya ikut Bunda Itoh (PAUD Yasmin), Bun. Melihat bagaimana pengurusannya, mengajak masyarakat, orang tua calon murid 
untuk ngobrol soal pentingnya PAUD bagi anak mereka. Awalnya memang susah, Bun, karena sebagian warga sini kalangan ekonomi lemah, $g a$ mikir gimana-gimananya. Tetapi setelah dikasih pencerahan sama $\mathrm{Bu}$ Yati dari Asih, pelan-pelan tuh Bun, mau... Apalagi melihat perkembangan anak didik bunda Itoh, pinter-pinter gitu"

Tidak jauh berbeda dengan penjelasan dari kepala sekolah PAUD Baitul Uyun :

"kami tuh dapat kontak $\mathrm{Bu}$ Yati, untuk mendapatkan pengetahuan, juga pengalaman bagaimana caranya mengelola PAUD, menyusun visi misi, mengajak orang tua biar mau nyekolahin anak di PAUD. Bu Yati dari Asih ngajarin semua, Bun, gimana baiknya dalam penyelenggaraan lembaga ini.

b. Selanjutnya YAF mendorong masyarakat untuk berperan aktif dalam pembangunan dan pengembangan Lembaga PAUD. Dengan dorongan dari YAF, terbukti elemen masyarakat (terutama para tokohnya) tanpa ragu mau menemui para calon orang tua murid dari rumah ke rumah untuk memberikan informasi, tujuan, dan manfaat berdirinya lembaga pendidikan tersebut. Hal ini dilakukan terutama bagi warga masyarakat yang mempunyai anak usia dini.

Seperti yang disampaikan oleh kepala Sekolah PAUD Nurunnajah :

"Sebagian orang tua, yang awalnya anteng, ga tertarik, akhirnya mau Bun, malah ujungunjungnya bantuin kita. Didatengin tuh satu satu para orang tua calon murid yang lain. Alhamdulillah, Bun. Sudah beberapa tahun terakhir selalu minimal kita terima 3 kelas, Bun"

Informasi tidak jauh berbeda disampaikan oleh Kepala Sekolah Baitul Uyun

"Awalnya susah banget Bun berharap partisipasi warga biar mau nyekolahin anaknya di PAUD. Tapi lama-lama warganya mau, sekarang Pak RT sering ikut mikirin gimana PAUD ini ke depan"

c. Peran berikutnya "menjadi penghubung Lembaga dan Wali Murid" hal ini terbukti dengan adanya program, kebijakan yang akan dilaksanakan, ataupun problema yang terjadi yang sekiranya tidak sampai mengumpulkan wali murid, yang disampaikan lewat masyarakat terutama yang termasuk dalam komunitas orang tua yang selalu mengantarkan anaknya.

d. Peran selanjutnya adalah "Membantu meningkatkan kualitas pendidikan" ini ditandai dengan suatu keputusan musyawarah YAF sebagai pengasuh dalam meningkatkan mutu pendidik dan masyarakat, diantaranya pendidik PAUD dikirim mengikuti penataran manajemen pengajaran PAUD.

“... diikutsertakan pelatihan untuk guru, baik dari Diknas, Perguruan Tinggi, atau Yayasan Asih sendiri, pokoknya kita sering diajak [...] yang ikut pelatihan harus berbagi pengetahuan dan skillnya kepada yang lain, biar ilmunya sama, ya setidaknya bedanya dikit lah. Misalnya saya pernah ikut pelatihan untuk sentra, guru yang lain pernah ikut studi banding ke PAUD lain yang masih di bawah ASIH juga. [...] 2 (dua) orang guru kita pernah diajak sama Bu Yati ikut pelatihan pendidik PAUD yang diselenggarakan oleh prodi PG PAUD Universitas Al Azhar Indonesia. [...] ikut pelatihan pengelolaan lembaga PAUD, baik yang diselenggarakan oleh Diknas setempat ataupun Perguruan Tinggi..."

Informasi yang sama juga diperoleh dari PAUD Nurunnajah,

"kita (kami) mah bareng, Bun dengan PAUD Yasmin. Hampir semua yang PAUD Yasmin ikut, kita (kami) juga ikut"

Informasi yang sedikit berbeda diperoleh dari PAUD Baitul Uyun,

"Selain pendidikan dan pengajaran, kami diajak Bu Yati ke bank sampah di daerah Bogor sana, Bun. Mungkin karena Bu Yati lihat lokasi kami deket banget dengan tumpukan sampah, harus diolah nih sampahnya biar anak-anak kami ga kebauan sampah [...] sampahnya diolah supaya memiliki nilai jual.

Ketika dilakukan triangulasi kepada $\mathrm{Bu}$ Yati dari YAF, beliau menyatakan

"Orang-orang ini kasihan, $\mathrm{Bu}$, masyarakat yang termasuk ekonomi lemah, sering dimarjinalkan. Susah buat dapat pendidikan dini, biasanya PAUDnya jauh, bikin orang tua males nganterin anaknya buat sekolah. Ini Alhamdulillaah ada yang mau kelola, ya kami bantu aja lah, dikit-dikit [...] Baitul Uyun ini $\mathrm{Bu}$, waktu pertama kali saya ke sini, aduuuuuuhhhhh, bau sampah dimanamana [...] ihh anak-anak gimana mau belajar kalau begitu. Saya aja awalnya jijik banget [...] mengajak pengelolanya ke bank sampah di Bogor. Setelah itu mereka (PAUD Baitul Uyun) malah berkreasi sendiri, barang yang awalnya sampah malah dijadikan alat permainan edukatif (APE)."

Pelatihan yang diberikan juga terkait pengelolaan 
keuangan lembaga PAUD, yang dapat memperbaiki fasilitas pembelajaran seperti komputer, VCD player, speaker active, kamera digital, dan perlengkapan APE lainnya baik indoor ataupun outdoor.

"Alhamdulillaah..., PAUD Yasmin sudah memiliki sejumlah sarana yang cukup lah, Bun. Ada komputer, VCD Player juga, lumayan"

Terkait dengan pemberdayaan masyarakat yang bertujuan supaya masyarakat yang diberdayakan menjadi lebih mandiri, hal itu juga yang dilakukan oleh YAF. Pembinaan hanya dilakukan selama 2 (dua) tahun saja, setelah itu lembaga PAUD binaan dilepas, dan hanya diberikan pendampingan berupa kunjungan dan pengecekan kondisi lembaga PAUD.

"Kami didampingi hanya dari 2009 hingga 2011. Setelah itu kami dibiarkan berusaha sendiri, toh kami sudah diikutkan banyak pelatihan, sudah kenal banyak orang, baik dari HIMPAUDI maupun Perguruan Tinggi [...] pendanaan untuk menambah fasilitas ya jangan dibantu lagi dong"

"masa Nurunnajah mau disusui terus, Bun, ya $g a$ bisa. Sekarang kami sedang membangun beberapa ruang kelas, dimana untuk dananya tidak diminta dari atau dicarikan oleh YAF, tetapi kami cari sendiri”

"saat ini Baitul Uyun sedang berusaha lebih memaksimalkan potensi sampah kami ini, Bun. Sayangnya masyarakat masih kurang tertarik ketika kami ajak untuk mengubah nilai sampah. Tetapi bagi lembaga-lembaga kecil lain, pengolahan sampah kami sudah cukup menarik, dan kadang mereka beli dari kami. Lumayan, Bu untuk nambahin dana buat menambah fasilitas"

$\mathrm{Bu}$ Yati dari YAF menjelaskan

"lembaga PAUD yang kaya gini tuh banyak sekali di Indonesia, kalau kami terus menerus membina yang ini terus, kapan mereka berdaya? Kapan kami bisa bantu lembaga PAUD yang lain? Sekarang cukuplah kami memantau dari jauh, seperti apa perkembangan mereka bertiga, sambil kami membina yang lain"

f. Peran berikutnya "pengadaan sarana dan prasarana". YAF ikut serta membantu Lembaga PAUD untuk dapat memiliki sarana dan prasarana penyelenggaraan pendidikan PAUD di Lembaga PAUD yang menjadi mitra.

Meskipun YAF tidak membantu finansial secara langsung dalam pengadaan sarana dan prasarana, tetapi membantu dalam hal mencarikan link atau networking. Seperti yang disampaikan oleh kepala sekolah PAUD Yasmin,

"Setelah ikut pelatihan sekali, kami jadi kenal banyak orang, banyak pihak yang berkaitan dengan penyelenggaraan PAUD, jadi kami suka tanya kalau ada beasiswa, atau dana buat bangun sekolah kita ini [...] kenalan dengan pengusaha pembuat APE ber SNI, Bun, lumayanlah, kita diajak ke tempatnya untuk melihat-lihat, meskipun tidak beli, setidaknya kita tahu perkembangan kreativitas APE"

Kepala Sekolah PAUD Nurunnajah menyatakan, "Selain mencari link untuk pelatihan-pelatihan berikutnya, saya juga mencari informasi beasiswa untuk guru-guru saya yang masih lulusan SMA atau D3"

Dengan link atau network dari pelatihan pertama, selanjutnya para pengelola lembaga PAUD ini merasa terbantu meski secara tidak langsung. Sejauh ini, meski tidak atas ajakan YAF, lembaga mereka tetap berhasil memperoleh link yang baru untuk pengadaan sarana dan prasarana, juga beasiswa serta kemudahan bagi para pendidik untuk meningkatkan kemampuannya.

Berdasarkan data di atas, terlihat bahwa YAF sudah membagikan pengetahuan, mencarikan link atau networking bagi lembaga-lembaga PAUD yang berada di bawah binaannya supaya dapat mandiri setelah YAF tidak lagi menaungi mereka. Terlihat bahwa upaya dari YAF menunjukkan kegiatan pemberdayaan masyarakat. YAF melakukan proses dengan mana orang menjadi cukup kuat untuk berpartisipasi dalam, berbagi pengontrolan atas, dan mempengaruhi terhadap, kejadian-kejadian serta lembaga-lembaga yang mempengaruhi kehidupannya. Pemberdayaan menekankan bahwa orang memperoleh keterampilan, pengetahuan, dan kekuasaan yang cukup untuk mempengaruhi kehidupannya dan kehidupan orang lain yang menjadi perhatiannya. (Parsons, 1994 : 106). Dengan bekal dari kunjungan ke bank sampah di Bogor, PAUD Baitul Uyun berhasil mengelola sampah di sekitar lembaga PAUD mereka menjadi APE, bahkan berhasil menjadi juara lomba kreativitas murid PAUD tingkat DKI Jakarta. Sementara PAUD yang lain berhasil menemukan link untuk beroleh beasiswa dan kemudahan melanjutkan pendidikan bagi guru PAUD mereka. 


\section{KESIMPULAN}

PAUD telah menjadi tanggung jawab bersama, orang tua, masyarakat dan pemerintah sebagai suatu dasar yang kokoh dalam pembentukan karakter dan kepribadian anak. PAUD diselenggarakan bagi anak sejak lahir sampai dengan enam tahun. Melalui penelitian ini dikatakan pendirian PAUD sangat berpengaruh terhadap perkembangan karakter, kepribadian, kebiasaan, perubahan sikap yang baik dan sosialisasi anak terhadap orang-orang disekitarnya. Jadi dalam usaha pembentukan karakter dan kepribadian anak PAUD memegang peranan yang sangat penting dan strategis. Adalah suatu penyesalan seumur hidup apabila anak kita memiliki karakter yang mengecewakan, tetapi kebahagiaan seumur hidup apabila anak kita memiliki karakter dan kepribadian luhur dan mulia.

Maka sebab itu Yayasan Asih Foundation bekerja sama dengan masyarakat disekitar untuk melakukan pengembangan pendirian PAUD di seluruh pelosok Indonesia guna membangun anak bangsa yang berkarakter. Pendirian sekaligus Pembinaan Lembaga PAUD oleh YAF menunjukkan adanya intervensi di level messo (Hardjomarsono, 2007: 1.10). Lembaga PAUD sendiri juga merasakan manfaat pembinaan YAF terhadap komunitas mereka. Beberapa Lembaga PAUD yang diteliti bahkan berhasil mengembangkan diri. Hal ini misalnya Kepala Sekolah Lembaga PAUD Baitul Uyyun di Cengkareng yang memilih mengikuti kursus Bahasa Mandarin atas biaya sendiri, lalu mengenalkan dasar-dasar Bahasa Mandarin kepada peserta didiknya. Tindakan tersebut diambil atas dasar pemikiran bahwa Bahasa Mandarin belakangan semakin dikenal luas di masyarakat Indonesia, dan AUD perlu mengenal bahasa asing lain selain Bahasa Inggris.

\section{Saran}

Berdasarkan temuan data di lapangan kami memberikan saran sebagai berikut :

1. Pembinaan terhadap lembaga PAUD diharapkan lebih lama, mengingat 2 tahun adalah masa yang relatif singkat untuk sebuah sekolah yang baru berdiri dari nol.

Seandainya tidak dapat dibina lebih dari 2 tahun, setidaknya dilakukan pendampingan secara berkesinambungan, terstruktur dan simultan selama 2 tahun

\section{DAFTAR PUSTAKA}

[1] http://www.eldina.com

[2] Direktorat PAUD, 2004

[3] http://www.junior-smart.com

[4] Ditjen PAUDNI, 2013. Kerangka Dasar Pembangunan PAUD Indonesia Periode 2011-2025, 2013

[5] Media Indonesia, 10 Juli 2006

[6] Siagian, S.P. 2001. Manajemen Sumber Daya Manusia, cetakan ke tujuh. Jakarta: PT. Bumi Aksara

[7] Siagian, S.P. 2007. Manajemen Sumber Daya Manusia. Jakarta: PT. Bumi Aksara

[8] Parsons, T 1974. in Turner, J.H. The Structur of Sociological Theory: Homewood, Illonois, The Dorsey Press.

[9] Suharto, E. 2002. Membangun Masyarakat Memberdayakan Rakyat. Bandung: PT. Refika Aditama

[10] Chambers, R. 1995. "Poverty and Livelihood: Whose Reality Count?" Dalam: People From Improverishment to Empowemnet. New York: Uner Kindar dan Leonard Silk (Eds), New York University Press

[11] Kartasasmita, G. 1997. Visi Pembangunan 2018: Tantangan Bagi Profesi Administrasi; Tulisan Pada Pembangunan Administrasi Indonesia. Jakarta: LP3ES.

[12] Bryant dan White. 1987. Manajemen Pembangunan Untuk Negara Berkembang, Cetakan Pertama, Alih Bahasa Rusyanto L. Simatupang, LP3ES, Jakarta

[13] Soetrisno, L. 1995. Menuju Partisipasi Masyarakat. Yogyakarta: Kanisius.

[14] Weissglass, J. 1990. Constructivist Listening for Empowerment and Change, The Educational Forum 54, No. 4.

[15] Irwin. Alan, 1995, Citizen Science: A Study of People, Expertise and Sustainable Development, London: Routledge

[16] Sumodiningrat, G. 1999. Pemberdayaan Masyarakat dan Jaringan Pengaman Sosial. Jakarta: PT. Gramedia Pustaka Utama.

[17] Hardjomarsono, B. 2007. Teori dan Metode Intervensi Sosial. Edisi 2. Buku Materi Pokok. Jakarta : Penerbit Universitas Terbuka

[18] Decker, C A dan Decker, J.R. 1992. Planning and Administering Early Childhood Program Fifth Edition, New York: Macmillan Publishing Company 
[19] Barnett, S.W. 2000, "Economic of Early Childhood Intervention" Handbook of Early Childhood Intervention, Second Edition Edited by Jack P. Shonkoff and Samuel J. Meisels, Cambridge: Cambridge University

[20] Piegas, Avezum, Pereira, Neto, Hoepfner, Farran, et al. Risk Factors for Myocardial Infarction in Brazil. American Heart Journal. 2003;146(2):331-8.

[21] Farran, D. C. 2000. "Another Decade of Intervention for Children Who Are Low Income or Disabled" Second Edition Edited by Jack P. Shonkoff and Samuel J. Meisels, Cambridge: Cambridge University
[22] Bogdan, R. and Taylor, S.J. 1975. Introduction to Qualitative Research Methode. New York : John Willey and Sons

[23] Pranarka dan Vidhandika M, "Pemberdayaan (Empowerment)", dalam Onny S. Prijono dan A.M.W Pranarka (eds), 1996. Pemberdayaan: Konsep, Kebijakan dan Implementasi, CSIS, Jakarta 